\title{
Transdisciplinary planning approaches towards resilience
}

\author{
Elizelle Juanee CILLIERS, North-West University, South Africa
}

\begin{abstract}
Urban functions are no longer separated spatially or socially, and the contest between diverse land-uses is reaching a peak due to growing populations and increasing urbanization that inflates the pressure on already strained resources within the urban fabric. The trend of depletion of green spaces is an increasing global phenomenon, intensifying the growing carbon footprint, impairing water quality and compromising health and overall quality of life, ultimately leading to cities that are far removed from the safe, clean, and livable environments, as envisioned in planning theory. Green spaces are often viewed as a "luxury good", despite the comprehensive literature on the extensive benefits of such spaces to their host cities and communities. Misconceptions relating to the notion of green spaces are reflected in the undervaluation of these spaces, under-prioritization in the budgeting process and ultimate negligence in terms of broader spatial planning approaches. The lack of function and ownership further exacerbate the social-and economic value of these green spaces, especially within the South African context, apparent by the disproval of the compensation hypothesis and rejection of the proximity principle. Much effort will be needed to change perceptions and sensitize decision-makers to understand green spaces as a "public good" and "economic asset". Resilience thinking could pose solutions in this regard, drawing on transdisciplinary planning approaches to manage change and steer Spatial Planning towards the era of transurbanism. It would however, require the emancipation of the disciplinary identity of Spatial Planning as crucial driver towards resilience, departing from theoretical and methodological frames of supplementary disciplines, as well as the indigenous knowledge and living experiences of communities, to co-produce urban innovations. Conveying strategic and lateral thinking, contemporary Planners would need to become generative leaders, with socio-emotional intelligence, to generate innovation and co-create solutions for strained social contexts, for depleting scare resources, for managing change of contemporary urban landscapes.
\end{abstract}

\section{Keywords}

Trans-disciplinary planning, green spaces, resilience

\section{The contemporary urban landscape}

The world population of today is growing by an average of 162,600 persons per day. Almost every spatial planning-orientated paper references the increasing world population in arguing the complexity of the planning profession to create a sustainable future. The planning profession has evolved from a designing art, to a social science (Zhang, 2006:12), to a management and applied science (Zhang, 2006:12; Cilliers \& Cilliers, 2016). Contemporary 
Spatial Planning is now confronted with "the management of change", to resolve conflicting political and social demands on space, while protecting the earth's generative capacity (Campbell, 1996:296; Cilliers \& Cilliers, 2016). Spatial change is at a peak within the urban landscape, as 4.2 billion of the world's 7.6 billion people (55\%) currently reside in cities (UN DESA, 2018). Projections show that urbanisation, the gradual shift from rural to urban areas, combined with the overall growth of the world's population could add another 2.5 billion people to urban areas by 2050 (reaching 68\% urbanisation), and reaching full global urbanisation in the following decades, intensifying the challenges of the contemporary urban landscape.

The four urban functions of working, living, leisure and transport which Le Corbusier (1929) once so elegantly deployed in his model of the city can no longer be separated from each other either spatially or socially (Mulder, 2002). The contemporary urban landscape deploys a picture where formal data (land-use, functions and zonings) are now distorted by informal data (activities and interaction) that precedes planning structures, as illustrated in Figure 1.

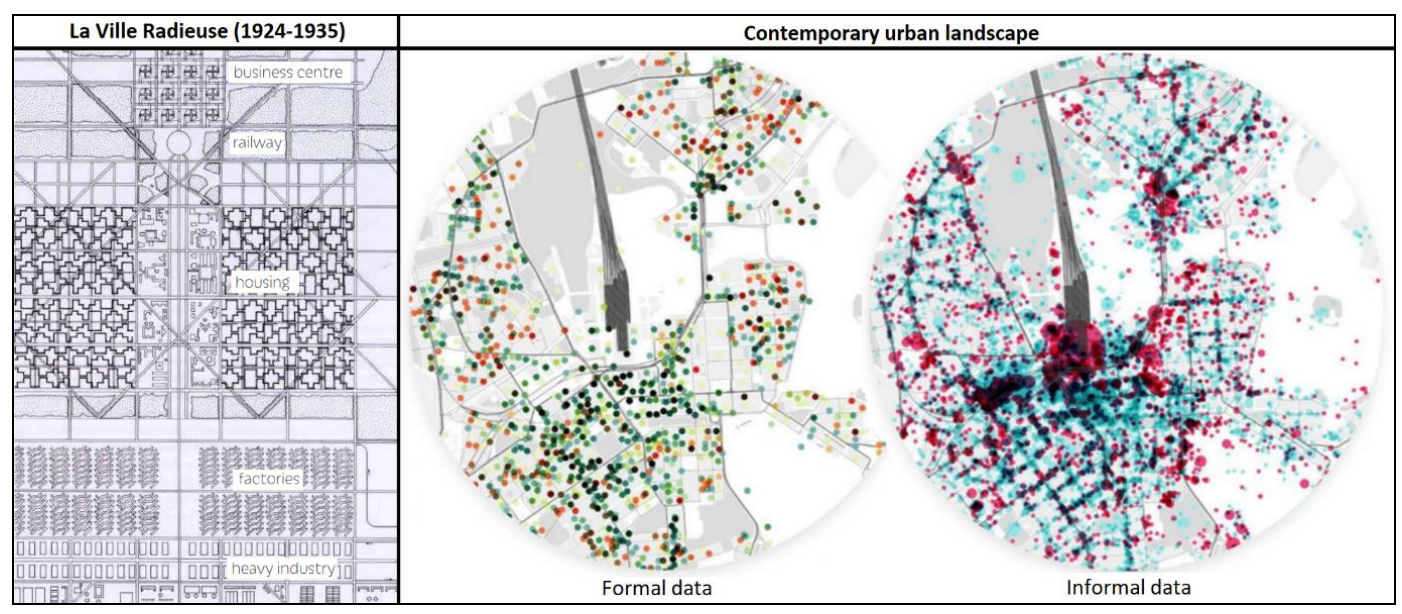

Figure 1: From La Ville Radieuse to the contemporary urban landscape Source: Based on Le Corbusier (1929) and Danin (2019)

In Africa, the expected rate of urbanisation poses a further concern in light of potential negative environmental impacts (Kestermont et al., 2011) that could lead to unprecedented changes, especially within a soon to be urbanised landscape, where informality and sustainability collide. Africa is in a unique position to embrace informality as a contributing factor to the realisation of broader sustainable development objectives, as argued by Lategan (2017) in reference to South Africa's informal backyard rental sector and its contribution to structuring sustainable urban landscapes. But, for Africa to lead this discourse on informality and sustainability, the African space economy should be reconsidered from a Spatial Planning perspective (Okeke, Cilliers and Schoeman, 2018), to facilitate ways to host growing populations, accommodate urbanisation and changing urban landscapes and social dynamics, while recognising land as a scarce resource, and as a force of global importance in the quest towards sustainable development (Sustainable Cities Institute, 2012; Cilliers \& Cilliers, 2015). 


\section{Land as a scarce resource of the contemporary urban landscape}

Land was once plenteous and resources were abundant. With the predictions of full global urbanisation within the next half century (McArthy, 2016), urgent action is needed to recognise land as a scarce resource of the contemporary urban landscape. Spatial planning has a key role to play in this regard, shaping the contemporary urban landscape in line with the universal ambition for sustainability, embedded in the global sustainable development goals (United Nations, 2017). In the search for "inclusive, safe, resilient and sustainable cities and human settlements" (United Nations, 2017), the interrelated role of the environment as catalyst to realises the objectives of sustainability (Anderson \& Elmqvist, 2012) is becoming more prominent. There is now an expanded scientific understanding that green spaces are substantially beneficial to urban communities and cities (Llausas \& Roe, 2012; Thomas \& Littlewood, 2010; Wright, 2011), and that ecological principles are a sine qua non for sustainable cities (Forman, 2013, Lui et al., 2007; Stigsdotter, 2008; Cilliers \& Cilliers, 2015).

However, despite theoretical and methodological frameworks in support of green spaces within the urban landscape, the reality suggests of a depletion of urban green spaces across the globe. Statistics illustrate, amongst others, a depletion of green spaces in 25 European cities (European Environmental Agency, 200), in 274 metropolitan areas in the United States of America (McDonald et al., 2010) and to an even greater extent in Africa (Cilliers et al., 2013; Kestermont et al., 2011). In South Africa, for example, green spaces occupy less than $10 \%$ of urban land (McConnachie et al., 2008). The lack of green spaces in high-density urban landscapes are in most cases a result of their susceptibility to urban development pressures (More et al., 1988:141; Luttik, 2000) and the under prioritisation of green spaces in the decision-making process (Bertaud, 2010). As a result, cities are being further removed from the safe, clean, and livable environments, envisioned in planning theory (Van den Berg et al., 2007).

Data from the Global Carbon Project (2018) illustrate that land-use changes, especially the depletion of green spaces and deforestation, comprised $11 \%$ of total emissions produced in 2017. Land as a scarce resource is thus becoming a force of global importance, as changes in land-use contribute to the growing carbon footprint (Global Carbon Project, 2018). Spatial Planning could influence both the release and uptake of carbon, by considering industry planning and emission of fossil fuels, emissions from land-use changes, protection of carbon sinks such as the oceans and land, and recognising planning as either catalyst, or inhibitor, of changes in atmospheric concentrations of $\mathrm{CO} 2$ (Global Carbon Project, 2018), as indicated in Figure 2. 


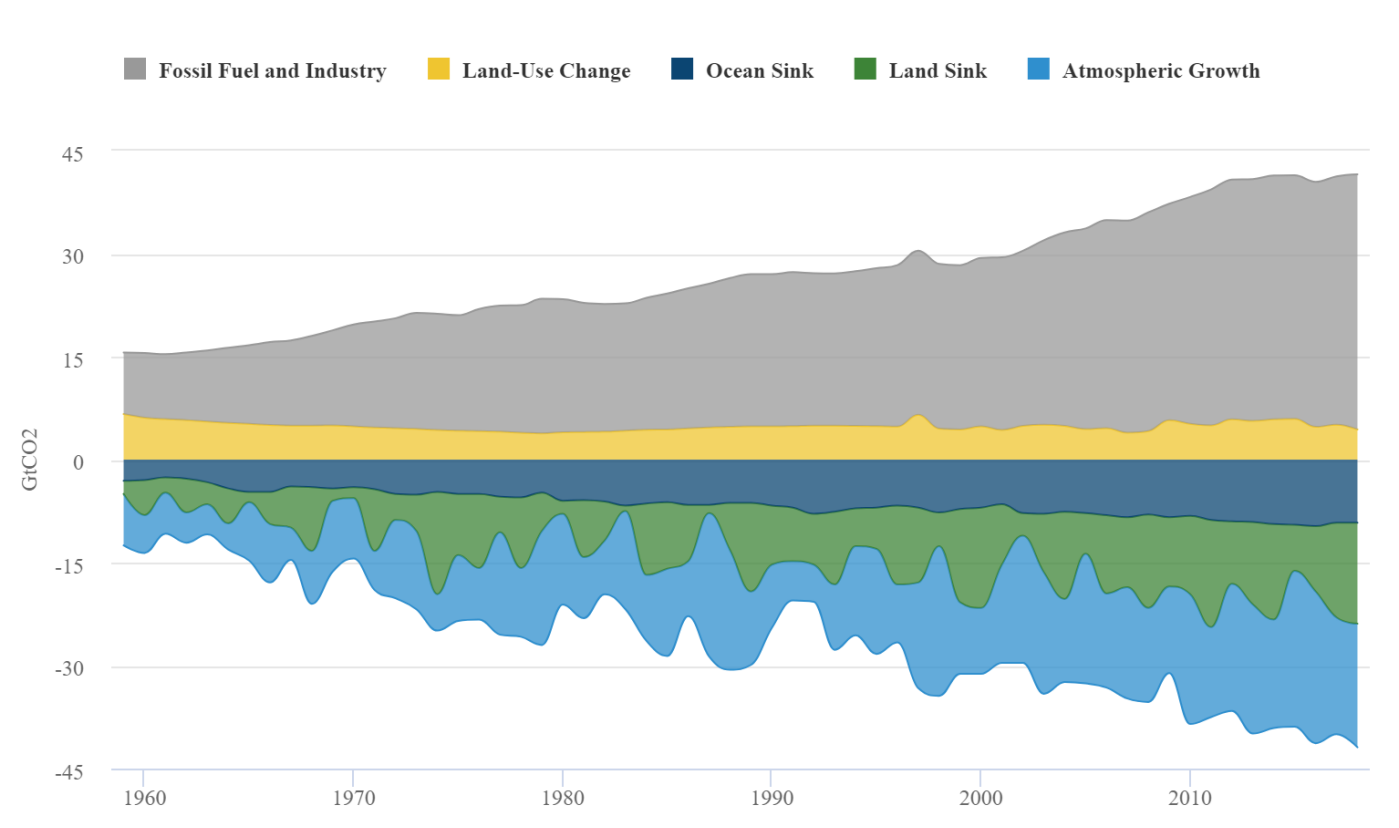

Figure 2: Annual global carbon budget of sources and sinks from 1959-2017 Source: Global Carbon Project (2018)

Cities have become a central nexus in the relationship between people and nature (Elmqvist, 2014), where the provision of green spaces results in a range of supplementary ecosystem services supporting humanity, including provisioning, regulating, supporting and cultural services (Cornelius, 2016:86; Cilliers et al., 2018), but concurrently, where the lack of green spaces, trigger other negative impacts, known as ecosystem disservices (Shackleton et al., 2016). These impacts relate to, but are not limited to, the intensified urban heat-island effect, increased energy consumption (Akbari, 2005), impaired water quality (James, 2002) and ultimately compromised human health and comfort (Centre for Disease Control and Prevention, 2006; EPA, 2019, Timmermans et al., 2017).

In the African urban landscape these impacts are magnified due to proportionally higher pressure on land use and loss of biodiversity per unit of wealth produced, compared to Europe (Cilliers et al., 2013). The prioritisation of green spaces in this context is also more complex, as strained social contexts often overshadow community needs. In many cases development-decisions precedes environmental concerns (Cilliers \& Cilliers, 2016; Thysse, 2017), in support of growing societies. Despite comprehensive evidence from literature and best practices pertaining to the value of green spaces as 'public goods', articulated in terms of ecological-, social-, and economic values (Cilliers \& Cilliers, 2016), green spaces are often considered a 'luxury good' in the African context and not a necessity or a sine qua non for sustainability (Cilliers and Cilliers, 2015; du Toit et al., 2018).

As a result, the "more pressing needs", such as eradicating poverty, providing basic services and addressing the growing housing backlog (Cilliers \& Cilliers, 2015; Soares et al., 2011; Cilliers \& Cilliers, 2016) take precedence in municipal and national budgets, only further constraining the planning and provision of green spaces in areas where it is often most needed (Cilliers \& Cilliers, 2016; Huston, 2016). The reluctance to budget and plan for green spaces should, however, not be confused with the community need in search of such spaces. Previous findings by Cilliers et al. (2013) demonstrated how the valuation of green spaces 
fluctuate against different socio-economic gradients, as poorer communities put a higher demand on provisioning services (food, lawn, medicinal, shade), while more affluent communities put a higher demand on cultural ecosystem services (aesthetics and ornamentals). More recent research suggests of a growing need for green spaces amongst local communities within the South African context (Lategan \& Cilliers, 2014).

The need of such green spaces are however, due to misconceptions and the lack of budgets and planning, not being met in practice. Research by Lategan and Cilliers (2014) considered the value of public green spaces and the informal backyard rental sector of Bridgton and Bongolethu (Oudtshoorn, South Africa) and concluded that green spaces in these areas are not providing any specific service to the communities and therefore, despite the need expressed for green spaces, not used by most individuals. The compensation hypothesis, which departed from the understanding that communities with limited access to private green space will seek compensation elsewhere, was disproved in the Bridgton and Bongolethu case study ( $\mathrm{N}=708$ ), further supporting the impact of impractical spaces. Such spaces do not provide a service to communities and do not entice users, who do not have access to ample domestic green space, to seek compensation in these public spaces (Lategan \& Cilliers, 2017; Maat \& De Vries, 2006; Lin et al., 2015).

The majority of local research suggest that green spaces in South Africa are not on par with international standards in terms of quality and function, strengthening the false perception that these spaces are not valuable or valued (Cilliers \& Cilliers, 2016). It is further posited that the lack of quality and function related to these green spaces explains for most part, why these green spaces do not increase property values in accordance with the internationally accepted green proximity principle which states that residential property prices increase as proximity to green space increases. This results and disproval of the green proximity principle, was derived from a local case study conducted in Potchefstroom (JB Marks Municipality, South Africa) where statistical analysis of variance (ANOVA) was applied to the property values of five residential areas to determine the significant difference between the means of properties located at different distances from an urban green space (Cilliers \& Cilliers, 2017). The collective results of the Potchefstroom Case study ( $N=188$ ) illustrated a statistical difference between zones located further from the green space $(p=0.76)$, thus rejecting the null hypothesis and disproving the proximity principle. Ecosystem disservices associated with crime in green spaces (Konijnendijk et al., 2013: 22) and the perception of green spaces as crime hotspots (Perry et al., 2010), were identified as possible contributing factors why residential properties located adjacent to green spaces exhibited a lower price per square meter than properties located further away. Cilliers and Cilliers (2016) identified a lack of function and ownership connected to green spaces, as contributing factor for negligence and failure of green spaces in local context.

In an attempt to steer the national vision towards realising the importance of green spaces within the urban landscape, the South African Cities Network (SACN) appointed Cilliers and Cilliers (2016) as authors of the publication "Planning for Green Infrastructure: Options for South African Cities"

This research introduced the notion of green infrastructure (GI) as a long-term strategic approach to plan green spaces as a network of supportive infrastructure. It contributed to the discourse on the valuation of public green spaces from different social and cultural gradients, as well as the discourse on user-values and valuation from a local perspective. It 
called for the integration of green infrastructure as part of mainstream Spatial Planning, recognising that much effort will be needed to change perceptions about the necessity of green spaces in both urban and rural landscapes in South Africa. To sensitise decisionmakers to grasp the value and role of green spaces as a 'public good' and 'economic asset', more practical guidance is needed (Cilliers et al. 2018) with a proactive and deliberate response to address contemporary challenges (Folke, 2006).

It mandates a shift towards resilience thinking in planning (Schoeman, 2017), where Spatial Planning response to the increasing economic, social and spatial vulnerabilities in cities, and halt the rapid depletion of natural resources and environmental degradation (Harrison et al., 2014). It implies planning structures and systems that will allow communities to endure change (Spacey, 2016) and for methods to explore the dynamics of the city and spatial systems in different ways (Schoeman, 2018). It calls upon a systems approach to planning contemporary urban landscapes, inclusive of learning and innovation (Schoeman, 2018). Such structures and systems demand transdisciplinary planning.

\section{Transdisciplinary planning towards resilience}

Transdisciplinary planning goes beyond the "primacy of science" (laypersons inputs in scientific research) as well as the "primacy of practice" (provision of classical decision support), establishing a third epistemic way (Wiek 2007; Jahn 2008; Bergmann et al. 2005) where experience-based guidelines find mutual grounds between all stakeholders (Cash et al. 2003). Transdisciplinary planning brings academic knowledge and non-academic knowledge, as illustrated in Figure 3.

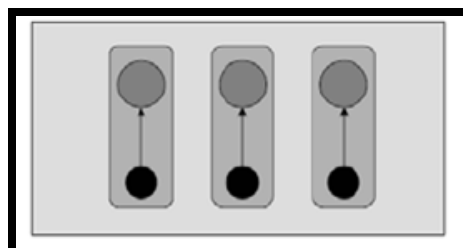

(a) Disciplinary

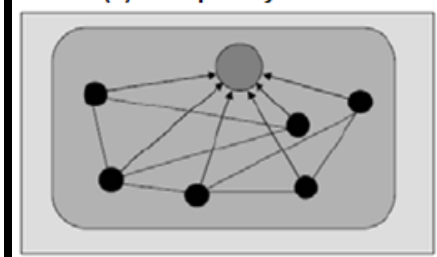

(c) Inter-disciplinary

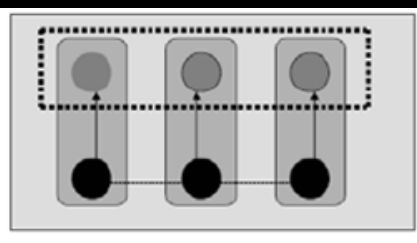

(b) Multi-disciplinary

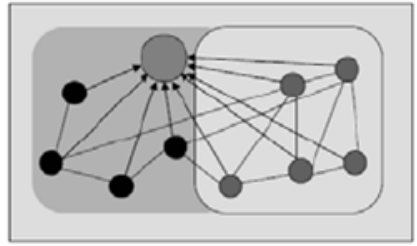

(d) Trans-disciplinary

\begin{tabular}{|l|l|}
$\begin{array}{l}\text { Discipline } \\
\text { Purpose }\end{array}$ & $\begin{array}{l}\text { Academic knowledge } \\
\text { Non-academic knowledge }\end{array}$ \\
\hline
\end{tabular}

Figure 3: Scope of disciplinary approaches in promoting the interface between disciplines Source: Fry et al (2007)

Transdisciplinary planning could strengthen the spatial meaning of resilience in the contemporary urban landscape, by capturing metabolic flows (production, supply and consumption chains), social dynamics (demographics, human capital and inequality), governance networks (institutional structures and organisation) and the built environment (ecosystem services in the urban landscape) (Harrison et al., 2014, Schoeman, 2018). 
Transdisciplinary planning provides a platform to explore the socially and spatially integrated dynamics of the urban landscape in different ways, as it calls upon a 'planning with' approach as referred to by Cilliers and Victor (2018). Such approach is grounded in anthropological understandings of space and cities as 'meshworks' (Ingold, 2016:10), which simultaneously draw on literature and concepts in spatial planning, in an attempt to make the argument for a 'planning with' approach 'policy relevant' (Spiegel, et al., 1999:182-186).

A 'planning with' approach draw on the expertise of transdisciplinary stakeholders, including the indigenous knowledge and lived experiences of local communities as agents of urban change. It contributes to realising the potential of integrative planning as it challenging professionals, scientists, authorities, policy-makers and local communities to take collective ownership of the direct environment (Cilliers \& Victor, 2018). It will align with transurbanism approaches that redefine urban life and introduces new politics of the urban landscape (Thrift, 2013), in relying on multiple stakeholders to collectively reorganise the urban landscape as a living structure, informed by the urban landscape itself (Mulder, 2002).

Such a transdisciplinary 'planning with' approach could place public green spaces as the common denominator for aligning informality and sustainability, when green spaces are perceived as a 'public good' and an 'economic asset' that can benefit both communities and their environment through the ecosystem services they provide. The valuation, and prioritization of green spaces in this sense, would not only advance supporting ecosystem services such as enhanced biodiversity (Cilliers et al., 2013), habitat provision (Stiles, 2006), and the provision of refuge to species that are disappearing from urban areas (Hodgkison \& Hero, 2007) but also regulating ecosystem services such as reduced atmospheric carbon dioxide (Cilliers et al., 2010) enhanced air quality (Bolund \& Hunhammer, 1999), countering heat island effects (Akbari et al., 2001), limiting noise pollution (Bolund \& Hunhammar, 1999), but would also result in multiple cultural ecosystem services (social benefits) such as physical (Kuo, 2003, Roger, 2003) and psychological restoration evident from the mediational analyses by Van den Berg et al. (2007), as well as increased levels of physical activity (Owen et al., 2004), stress relief (Hansmann et al., 2007), happiness (Chiesura, 2004) and better neighbour relationships (Roger, 2003). It would further entail cultural ecosystem services with economic benefits relating to increased tourism (Wooley et al., 2003), enhanced local investment in the area (Cabe Space, 2009), increased property values (Luttik, 2000) and overall improvements in quality of life (Schultz and King, 2001; Smith et al., 2002).

Spatial Planning will still be confronted with the management of change, but the emphasis will shift from land-use, towards managing interaction between space, activities, and values (Danin, 2019). Interaction planning might soon become the new axiom (Danin, 2019) of the contemporary urban landscape as transdisciplinary research feeds into values to inform smart spatial data towards informed decision-making and good governance.

Finally, in agreement with Pinson (2004), disciplinary identity should remain as a precondition of transdisciplinary collaboration. Thus, while other mature sciences may, and should, contribute to the urban dialog, Spatial Planning should emancipate itself from these theoretical and methodological frames to further construct its own identity (Pinson, 2004) as a global scarce skill and national priority, to give spatial meaning to supplementary disciplines. Conveying such strategic and lateral thinking, Planners would need to become generative leaders. Moving away from adaptive leadership that is motivated by challenges or problems (Senge, 1990) and moving towards generative leadership, that recognizes and 
taps into collective intelligence and energy to generate effective solutions (Klimek et al., 2008:2). Such leaders have courage and an acute level of socio-emotional intelligence to identify the core issues to be addressed, and to frame these issues in a manner that will motivate a variety of stakeholders to engage in creating urban innovations (Bushe, 2019).

Such Planners would be able to co-produce innovation to address the great questions of our time: How to embedded resilience thinking in managing change of contemporary urban landscapes by also asking the questions of resilience for whom, resilience from what to what, and resilience when, where and why (Meerow \& Newell, 2017). How to transform and decolonize planning in Africa to be inclusive. How to find sustainability within informality? Academia stand central to developing socio-emotional intelligence as a soft skill for contemporary and future planners and generative leaders. that would require a greater emphasis on experiential learning, a methodology within social constructivism, to learn through experience, and "learn through reflection on doing" (Felicia, 2011) embracing also a "safe to fail" approach in urban planning and design (Ahern et al., 2014). It is through such inquiry-based approaches that we can collectively become co-producers of knowledge (Tengo et al., 2014) and agents of future change, needed to collectively, build the city.

"We have one half century left to get urbanisation right".

The time for generative Planners to rise, is now.

\section{References}

1. Akbari, H. 2005. Energy Saving Potentials and Air Quality Benefits of Urban Heat Island Mitigation (19 pp, 251K). Lawrence Berkeley National Laboratory.

2. Akbari, H., Pomerantz, M. \& Taha, H. 2001. Cool surfaces and shade trees to reduce energy use and improve air quality in urban areas. Solar Energy, Vol. 70(3): 295-310.

3. Anderson, P., Elmqvist, T., 2012. Urban Ecological and Social-Ecological Research in the City of Cape Town: Insights Emerging from an Urban Ecology CityLab. Ecology \& Society 17(4): 269-273.

4. Bergmann, M., Brohmann, B., Hoffmann, E., Loibl, M.C., Rehaag, R., Schramm, E. \& Voß, J-P. 2005. Quality criteria of transdisciplinary research. A guide for the formative evaluation of research projects. ISOE-Studientexte, No 13, Frankfurt am Main, Germany

5. Bertaud, A. 2010. The study of urban spatial structures. Available at http://alainbertaud.com. Date of access: 20 January 2018.

6. Bolund, P. \& Hunhammar, S. 1999. Ecosystem services in urban areas. Ecological Economics, Vol. 29(2): 293-301.

7. Brand Finance. 2015. Lego Overtakes Ferrari as the World's Most Powerful Brand. Brand Finance. 17 February 2015. Retrieved 20 January 2019.

8. Burgess, R. 2000. The compact city debate: A global perspective. In M. Jenks \& R. Burgess (Eds.), Compact cities: Sustainable urban forms for developing countries (pp. 9-24). London: E., \& F. N. Spon.

9. Bushe, G. 2019. We need generative leadership in a VUCA world. HR Magazine, 9 Jan 2019. Available at: https://www.hrmagazine.co.uk/article-details/we-need-generative-leadershipin-a-vuca-world\#.XErgjeRvYbM.linkedin. Date retrieved: 25 January 2019.

10. Cabe Space. 2005. Paying for parks: Eight models for funding urban green space. London, 2005. Available at: www.cabe.org.uk/files/Paying-for-parks-full-report.pdf. Accessed on: 20 April 2018.

11. Cash, D.W., Clark, W.C., Alcock, F., Dickson, N.M., Eckley, N. \& Gurston, D.H. 2003. Knowledge systems for sustainable development. Proc National Academic Sciences USA, Vol. 100: 8086-8091 
12. Center for Disease Control and Prevention. 2006. Extreme Heat: A Prevention Guide to Promote Your Personal Health and Safety.

13. Chiesura, A. 2004. The role of urban parks for the sustainable city. Landscape and Urban Planning, Vol. 68: 129-138.

14. Cillieres, E.J 2009. The Urban Development Boundary as a Planning Tool for Sustainable Urban Form: The South African Situation. International Journal of Social, Behavioural, Educational, Economic, Business and Industrial Engineering, Vol. 3(6): 942-947. World Academy of Science, Engineering and Technology. DOI: scholar.waset.org/1999.10/12075 http://waset.org/publications/12075/the-urban-development-boundary-as-a-planning-toolfor-sustainable-urban-form-the-south-african-situation

15. Cilliers, E.J 2009. Bridging the Green-Value-Gap: A South African Approach. International Journal of Social and Human Sciences, 3 (2009): 615-620, ISSN 2070-3740 and World Academy of Science, Engineering and Technology International Journal of Environmental, Chemical, Ecological, Geological \& Geophysical Engineering, Vol. 3(6): 182-187.

16. Cilliers, E.J. \& Cilliers, S.S. 2015. From green to gold: A South African example of valuing urban green spaces in some residential areas in Potchefstroom. Town and Regional Planning, Vol. 67: 1-12.

17. Cilliers, E.J. \& Cilliers. S.S 2016. Planning for Green Infrastructure: Options for South African Cities. South African Cities Network, Johannesburg. Aug 2016. ISBN: 978-0-620-72315-2, 56p. http://www.sacities.net/wpcontent/uploads/2016/PDF/SAcities_GreenerCities_Web.pdf 6 citations. http://www.sacities.net/planning-for-green-infrastructure-options-for-south-african-cities Publisher: South African Cities Network (C), August 2016).

18. Cilliers, E.J. \& Schoeman, C.B. 2008. Urban Development Boundary as a Planning Tool for Sustainable Urban Form. WIT Transactions on Ecology and the Environment, Vol. 117: 85-94. ISSN 1743-3541 (on-line). DOI: 10.2495/SC080091

19. Cilliers, E.J. 2019. Reflecting on Green Infrastructure and Spatial Planning in Africa: The Complexities, Perceptions, and Way Forward. Sustainability, Vol. 11(2). ISSN: 2071-1050. https://www.mdpi.com/journal/sustainability

20. Cilliers, E.J. \& Victor, H. 2018. Considering Spatial Planning for the Poor: The argument of "planning with". Town and Regional Planning, Vol. 72: 29-41. University of the Free State. ISSN: 1012-280X. http://dx.doi.org/10.18820/2415-0495/trp72i1.3

21. Schoeman, C.B. 2018. Theoretical perspectives on resilience and sustainability in transportation and spatial planning. International Journal of Development Planning, Vol. 13(2): $25-225$.

22. Cilliers, E.J., Cilliers, S.S. \& Lategan, L.G. 2018. Nature-based solutions in urban planning and design in developing countries: a South-African case study of a public open space. Through Local Eyes: Place-based approaches to emerging architectural, urban design and planning challenges in Africa and the Global South, Addis Ababa, 29-31 October 2018. https://www.conferenceaddis2018.org/ https://docs.wixstatic.com/ugd/f922b2_34a64e3415614d6ab504781dce6013aa.pdf

23. Cilliers, E.J., Cilliers, S.S., 2015. From green to gold: A South African example of valuing urban green spaces in some residential areas in Potchefstroom. Town Planning Review, 67: 1-12. ISBN: 1012-280

24. Cilliers, E.J., Diemont, E., Stobbelaar, D.J. \& Timmermans, W. 2010. Sustainable Green Urban Planning: The Green Credit Tool. Journal of Place Management and Development, Vol. 3(1):57-66. ISSN: 1753-8335. Emerald Insight. http://www.emeraldinsight.com/doi/abs/10.1108/17538331011030275

25. Cilliers, E.J., Timmermans, W., Van den Goorbergh, F. \& Slijkhuis, J.S.A. 2015. Green Placemaking in Practice: From Temporary Spaces to Permanent Places. Journal of Urban Design, Vol. 20(3): 349-366. Taylor \& Francis Online. http://www.tandfonline.com/doi/abs/10.1080/13574809.2015.1031213?journalCode=cjud2 0 
26. Cilliers, S.S., Cilliers, E.J., Lubbe, C.E., \& Siebert, S.J. 2013. Ecosystem services of urban green spaces in African countries-perspectives and challenges. Urban Ecosystems, Vol. 16(4): 681702. ISBN: 1573-1642. Springer Publishers. DOI 10.1007/s11252-012-0254-3.

27. Cornelius, A. 2016. Health clinic gardens in North - West Province, South Africa, as complex social - ecological systems Health clinic gardens in North-West Province, South Africa, as complex social-ecological systems Magister Scientiae in.

28. Cornelius, G.S.; Viviers, J.; Cilliers, E.J.; Niesing, C. 2017. Considering complexities in unique African planning approaches: Abstracting the role of African Urban Residents. WIT Trans. Ecol. Environ. Vol. 223: 415-426.

29. Danin, V. 2019. How Urban planning is turning into interaction planning. Future Urban Profession. Article series on all things urban. Available at: http://popupcity.net/52789 Date of access: 4 February 2019.

30. Dobbs, C., Escobedo, F.J. \& Zipperer, W.C. 2011. A framework for developing urban forest ecosystem services and goods indicators. Landscape and Urban Planning, Vol. 99: 196-206.

31. Ellis, S.M. \& Steyn, H.S. 2013. Practical significance (effect sizes) versus or in combination with statistical significance ( $p$-values). Manag. Dyn. Vol. 12: 51-53.

32. EPA (United States Environmental Protection Agency). 2019. Heat Island Impacts. Heat Island Reduction Program. Available at: https://www.epa.gov/heat-islands/heat-island-impacts Date of access: 4 February 2019.

33. European Environment Agency (EEA). 2002. Toward an urban atlas: Assessment of spatial data on 25 European cities and urban areas. Environmental Issue Rep. 30, EEA: Copenhagen.

34. Felicia, P. 2011. Handbook of Research on Improving Learning and Motivation. p. 1003. ISBN 1609604962.

35. Folke, C. 2006. Resilience: the emergence of a perspective for social-ecological system analyses. Global Environmental Change, Vol. 16(3): 253-267.

36. Forman, T.T. 2013. Ecological resilience as a foundation for urban design and sustainability', in Pickett, S.T.A., Cadenasso. M.L., \& McGrath, B. (eds.), Resilience in ecology and urban design, Dordrecht Heidelberg New York London: Springer, New York

37. Fry, G., Tress, B. \& Tress, G. 2007. Integrative landscape research: facts and challenges. Key topics in Landscape Ecology. Cambridge University Press, New York.

38. Global Carbon Project. 2018. Carbon budget and trends 2018. Available at: www.globalcarbonproject.org/carbonbudget Date of access: 28 January 2019.

39. Hansmann, R., Hug, S.M \& Seeland, K. 2007. Restoration and stress relief through physical activities in forests and parks. Urban Forestry \& Urban Greening, Vol. 6: 213-225.

40. Harrison, P., Bobbins, K., Culwick, C., Humby, T.L., La Mantia, C., Todes, A. \& Weakley, D. 2014. Urban Resilience Thinking for Municipalities. University of the Witwatersrand, Gauteng City-Region Observatory. Available at: http://wiredspace.wits.ac.za/bitstream/handle/10539/16490/URreport_1901MR.pdf?seque nce=3\&isAllowed=y Date of access: 4 February 2019.

41. Hodgkison, S. \& Hero, J.M. 2007. The efficacy of small-scale conservation efforts, as assessed on Australian golf courses. Biological Conservation, Vol. 135(4): 576-586.

42. Huston, G.D. 2016. Evaluating Local Green Infrastructure Training and Education Approaches within Urban Planning Curricula. Research for the Partial Fulfilment of the Degree B.Art et Scien (Planning); North-West University: South Africa, 2016.

43. Ingold, T. 2016. On human correspondence. Journal of the Royal Anthropological Institute, (N.S.): 23:9-27.

44. Jacobs, N.S. 2016. The Regeneration of Klerksdorp's CBD: A Greening Approach. Research for the Partial Fulfilment of the Degree B.Art et Scien (Planning); North-West University: South Africa, 2016.

45. Jahn, T. 2008. Transdisciplinarity in the practice of research. In Bergmann M, Schramm E (eds) Transdisziplina“re Forschung: Integrative Forschungsprozesse verstehen und bewerten. Campus Verlag, Frankfurt/Main, Germany, pp 21-37 
46. James, P., Tzoulas, K., Adams, M.D., Annett, P., Barber, A. \& Box, J. 2009. Towards an integrated understanding of green space in the European built environment. Urban For. Urban Green. Vol. 8:65-75.

47. James, W. 2002. Green roads: research into permeable pavers. Stormwater Vol. 3(2): 48-40.

48. Jenks, M., Burton, E., \& Williams, K. 1996. The compact city: A sustainable urban form? London: E., \& F. N. Spon.

49. Kestermont, B., Frendo, L., \& Zaccaï, E. 2011. Indicators of the impacts of development on environment: A comparison of Africa and Europe. Ecological Indicators, Vol. 11: 848-856.

50. Klimek, K. J., E. Ritzenhein, and K. D. Sullivan. 2008. Generative leadership: Shaping new futures for today's schools. Thousand Oaks, CA: Corwin Press.

51. Konijnendijk, C.C., Annerstedt, M., Nielsen, A.B. \& Maruthaveeran, S. 2013. Benefits of Urban Parks: A systematic review. A Report for IFPRA, Copenhagen \& Alnarp, January 2013.

52. Korsgaard, L. \& Schou, J.S. 2010. Economic valuation of aquatic ecosystem services in developing countries. Water Policy, Vol. 12: 20-31.

53. Kuo, F.E. 2003. The role of arboriculture in a healthy social ecology. Journal of Arboriculture, Vol. 29(3): 148-155.

54. Kuruneri-Chitepo, C.; Shackleton, C.M. 2011. The distribution, abundance and composition of street trees in selected towns of the Eastern Cape, South Africa. Urban For. Urban Green. Vol. 10:247-254.

55. Lategan, L.G. \& Cilliers, E.J. 2014. The value of public green spaces and the effects of South Africa's informal backyard rental sector. WIT Transactions on Ecology and the Environment, Vol. 191: 427-438. ISSN 1743-3541 (on-line). DOI: 10.2495/SC140361

56. Lategan, L.G. \& Cilliers, E.J. 2017. Considering urban green space and informal backyard rentals in South Africa: Disproving the compensation hypothesis. Town and Regional Planning, Vol. 69: 1-11. ISSN: 1012-280X http://hdl.handle.net/11660/5737

57. Lategan, L.G. 2016. Informality and sustainability: reflecting on South Africa's informal backyard rental sector from a planning perspective. Doctoral Thesis submitted for completion of the degree PhD Urban and Regional Planning, North-West University, Potchefstroom Campus.

58. Lategan, L.G.; Cilliers, E.J. Considering urban green space and informal backyard rentals in South Africa: Disproving the compensation hypothesis. Town Reg. Plan. 2016, 69, 1-18.

59. Le Corbusier. 1929. The City of Tomorrow and its Planning. London: John Rodker.

60. Lin, B.; Meyers, J.; Barnett, G. 2015. Understanding the potential loss and inequities of green space distribution with urban densification. Urban For. Urban Green. Vol. 14: 952-958.

61. Liu, Z., Mao, F., Zhou, W., Li, Q., Haung, J. \& Zhu, X. 2007. Accessibility Assessment of Urban Green Space: A Quantitative Perspective; School of Architecture, Tsinghua University: Beijing, China.

62. Liu, Z., Mao, F., Zhou, W., Li, Q., Haung, J., Zhu, X., 2007. Accessibility assessment of urban green space: a quantitative perspective. School of Architecture, Tsinghua University. Beijing.

63. Llausàs, A., Roe, M., 2012. Green Infrastructure planning: Cross-national analysis between the North East of England (UK) and Catalonia (Spain). European Planning Studies 20(4): 641663.

64. Luttik, J. 2000. The value of trees, water and open space as reflected by house prices in the Netherlands. Landscape Urban Planning, Vol. 48(3): 161-167

65. Lutzenhisher, M. \& Netusil, N.A. 2001. Effect of Open Spaces on a Home's Sale Price. Contemporary Economic Policy, Vol. 19: 291-298.

66. Maat, K.; de Vries, P. 2006. The influence of the residential environment on greenspace travel: Testing the compensation hypothesis. Environ. Plan. A Vol. 38: 2111-2127.

67. MaConnachie, M.M., Shackleton, C.M. \& McGregor, G.K. 2008. The extent of public green space and alien plant species in 10 small towns of the Sub-Tropical Thicket Biome, South Africa. Urban Forestry and Urban Greening, Vol. 7: 1-13. 
68. McDonald, R.I., Forman, R.T.T. \& Kareiva, P. 2010. Open space loss and land inequality in United States' cities, 1990-2000.PLoSONE, Vol. 5(3), e9509. doi:10.1371/journal.pone.0009509

69. More, A.T., Stevens, T. \& Allen, P.G. 1988. Valuation of Urban Parks. Landscape and Urban Planning, Vol. 15: 139-152.

70. Mulder, A. 2002. TransUrbanism: Arjun Appadurai, Arjen Mulder, Knowbotic Research, Lars Spuybroek, Scott Lash, Rafael Lozano-Hemmer, Andreas Ruby, Edward Soja, Rem Koolhaas, Brett Steele, Roemer Van Toorn, Mark Wigley. V2_publishing.

71. Niemelä, J., Saarela, S.R., Söderman, T., Kopperoinen, L., Yli-Pelkonen, V., Väre. S. \& Kotze, D.J. 2010. Using the ecosystem approach for better planning and conservation of urban green spaces: a Finland case study. Biodiversity Conservation, Vol. 19: 3225-3243

72. Okeke, D.C., Cilliers, E.J., \& Schoeman, C.B. 2018. Neo-mercantilism as development ideology - a conceptual approach to rethink the space economy in Africa. African Studies, Vol 77: 2352. ISSN 0002-0184. http://www.tandfonline.com/doi/full/10.1080/00020184.2017.1390912.

73. Olazabal, M., Chelleri, L., Waters, J.J. \& Kunath, A. 2012. Urban resilience: towards an integrated approach. $1^{\text {st }}$ International Conference on Urban Sustainability \& Resilience, London, United Kingdom, ISSN 2051-1361.

74. Owen, N., Humpel, N., Leslie, E., Bauman, A \& Sallis, J.F. 2004. Understanding environmental influences on walking: Review and research agenda. American Journal of Preventive Medicine, Vol. 27: 67-76.

75. Perry, E.D., Moodley, V. \& Bob, U. 2010. Open Spaces, Nature and Perceptions of Safety in South Africa: A Case Study of Reservoir Hills, Durban. School of Environmental Science, University of KwaZulu-Natal. 17p.

76. Pinson, D. 2004. Urban Planning: An 'Undisciplined' Discipline? Futures, Elsevier, Transdisciplinarity, Vol. 36(4): 503-513.

77. Roger, S.U. 2003. On health benefits of gardens in hospitals: Plants for People, Texas: Centre for health systems and design.

78. Schoeman, C.B. 2017. Theoretical perspectives on resilience and sustainability in transportation and spatial planning. International Journal of Sustainable Development Planning, Vol. 13(2): 215-225.

79. Senge, P. 1990. The Fifth Discipline: The Art and Practice of the Learning Organization. New York: Doubleday/Currency.

80. Shultz, S.D. \& King, D.A. 2001. The Use of Census Data for Hedonic Price Estimates of OpenSpace Amenities and Land Use. Journal of Real Estate Finance and Economics, Vol. 22: 239-252.

81. Soares, A.L., Rego, F.C., McPherson, E.G., Simpson, J.R., Peper, P.J. \& Xiao, Q. 2011. Benefits and costs of street trees in Lisbon, Portugal. Urban Forestry \& Urban Greening, Vol. 10(2): 69-78.

82. Spacey, J. 2016. Sustainability versus resilience. Simplicable. Available at: https://simplicable.com/new/sustainability-vs-resilience Date of access: 4 February 2019.

83. Spiegel, A. D., Watson, V. \& Wilkinson, P. 1999. Speaking truth to power? Some problems using ethnographic methods to influence the formulation of housing policy in South Africa. (In Cheater, A., ed. The anthropology of power: empowerment and disempowerment in changing structures. London: Routledge. p. 175-190).

84. SPLUMA. 2016. Spatial Planning and Land Use Management Act. Government Notice 559 in Government Gazette 36730 dated 5 August 2013. Commencement date: 1 July 2015 [Proc. No. 26, Gazette No. 38828 dated 27 May 2015]

85. Stigsdotter, U.A. 2008. Urban Green Spaces: Promoting Health through City Planning; Swedish University of Agricultural Sciences: Uppsala, Sweden, 2008; 17p.

86. Stiles, R. 2006. Urban spaces - enhancing the attractive-ness and quality of the urban environment. WP3 Joint Strategy. University of Technology, Vienna, December 2006. 
87. Sustainable Cities Institute. 2012. Land use. The National League of Cities. Available at http://www.sustainablecitiesinstitute.org/Documents/SCl/Topic_Overviews/Land\%20Use\%2 0-\%20Full\%20OverviewNew_NLC.pdf (Date of access: 22 March 2016).

88. Thomas, K., Littlewood, S. 2010. From green belts to green infrastructure? The evolution of a new concept in the emerging soft governance of spatial strategies. Planning, Practice \& Research, 25(2): 203-222.

89. Thrift, N. 2013. Transurbanism. Urban Geography, Vol 25(8): 724-734.

90. Thysse, A. 2017. Whose Role is It Anyway: Considering Project Management and Green Infrastructure Planning. Research for the Partial Fulfilment of the Degree B.Art et Scien (Planning); North-West University: South Africa, 2017

91. Timmermans, W., Jacobs, C., Van Hattum, T., Lategan, L.G. \& Cilliers, E.J. 2017. Ecosystembased climate change adaptation for Essenvelt, Middelbug, The Netherlands. Town and Regional Planning, Vol. 71: 24-35. University of the Free State. ISSN: 2415-0495. DOI: http://journals.ufs.ac.za/index.php/trp/article/view/3323

92. UN DESA. 2018. Sustainable Development Knowledge Platform. World Urbanisation prospects. United Nation DESA population division. Available at: https://population.un.org/wup/ Date retrieved: 20 January 2019.

93. United Nations. 2017. Progress towards the Sustainable Development Goals. Report to the Secretary-General. E/2017/66. Available at:

http://www.un.org/ga/search/view_doc.asp?symbol=E/2017/66\&Lang=E Date of access: 5 Jul 2017.

94. Van den Berg, A.E., Hartig, T. \& Staats, H. 2007. Preference for Nature in Urbanised Societies: Stress, Restoration, and the Persuit of Sustainability. Journal of Social Issues, Vol. 63(1): 7996.

95. Van Leeuwen, E., Nijkamp, P. \& de Norohna Vaz, T. 2010. The multi-functional use of urban green space. International Journal of Agric. Sustainability, Vol. 8: 1-13.

96. WCED. 1987. Special Working Session. "World Commission on Environment and Development." Our common future (1987).

97. Wiek, A. 2007. Challenges of transdisciplinary research as interactive knowledge generation-experiences from transdisciplinary case study research. GAIA Ecological Perspective on Science Society, Vol. 16:52-57

98. Woolley, H., Swanwick, C. \& Dunnet, N. 2003. On nature, role and value of green space in towns and cities: an overview. 2003. www.atypomlink.com/ALEX/doi/abs/10.2148/benv.29.2.94.54467.

99. Wright, H. 2011. Understanding green infrastructure: the development of a contested concept in England. Local Environment, 16(10): 1003-109. 